\title{
Application of Sugar Foam to Vineyard Acid Soils under Medi- terranean Conditions
}

\author{
M.A. Olego ${ }^{1 *}$, J.J.R. Coque², E. Garzón Jimeno ${ }^{3}$
}

(1) Instituto de Investigación de la Viña y el Vino (IIVV), Universidad de León, Avenida de Portugal, 41, 24071 León, España; E-mail address:molem@unileon.es

(2) Instituto de Investigación de la Viña y el Vino (IIVV), Universidad de León, Avenida de Portugal, 41, 24071 León, España; E-mail address: jegarj@unileon.es

(3) Instituto de Investigación de la Viña y el Vino (IIVV). Universidad de León. Avenida de Portugal, 41, 24071 León, España; e-mail: jjrubc@unileon.es

Submitted for publication: August 2013

Accepted for publication: July 2014

Key words: Liming, linear model, cross-validation, petiole, cane

Calcium (Ca) deficiency and aluminium (Al) toxicity are considered major chemical constraints that limit vine growth in vineyard acid soils under Mediterranean conditions. The main aim of this work was to evaluate the effects of three doses of sugar foam $(900,1800$ and $2700 \mathrm{~kg} \mathrm{CaCO} /$ /ha) on five soil properties ( $\mathrm{pH}$ in water, $\mathrm{Ca}, \mathrm{Mg}, \mathrm{K}$ and $\mathrm{Al}$ exchangeable contents) and $\mathrm{Ca}$ concentrations in petioles and canes of one wine grape variety. Research was conducted over three seasons (2006 to 2008) in a random block design at León (Spain). The results for plants and soils were subjected to general lineal model analysis. As a result, one linear model, validated through a cross-validation procedure, has been proposed to predict exchangeable calcium levels in vineyard acid soils at véraison. Based on the results for the soils, the higher doses of sugar foam (1 800 and $2700 \mathrm{~kg} \mathrm{CaCO} / \mathrm{ha}$ ) were the most effective doses in decreasing $\mathrm{Al}$ exchangeable and increasing $\mathrm{Ca}$ exchangeable contents. In addition, liming increased $\mathrm{Ca}$ content in petioles and decreased Ca content in canes, but in both cases these differences were not significant.

\section{INTRODUCTION}

Soil acidity is a major limitation to soil productivity in many regions around the world. The adjustment and maintenance of soil acidity to a level suitable for grape production is an important first step in the management of an acid soil dedicated to Vitis vinifera L. Soil acidity can affect various factors that contribute to the biological, chemical and physical properties of soil that make it best able to fulfil its desired purpose. Grape production systems undergo accelerated soil acidification as a consequence of anthropogenic inputs and outputs. The resultant decline in soil $\mathrm{pH}$ associated with grape production systems may be sufficient to cause moderate to severe $\mathrm{Al}$ and manganese $(\mathrm{Mn})$ toxicity, thereby affecting the long-term economic viability of vineyard production and resulting, in some cases, in permanent degradation of the soil as a resource base (Sumner \& Noble, 2003).

Aluminium toxicity is recognised as the main limiting factor for plant growth on acid soils (Kochian et al., 2005). Although there are no identifiable symptoms of $\mathrm{Al}$ toxicity suitable for use as a diagnostic indicator, the most apparent effects are a reduction in both root and shoot growth (Menzies, 2003). However, the Al concentration in the soil solution is not the only important growth-limiting parameter in grape production on acid mineral soils. Instead, toxicity is modulated by $\mathrm{Al}$ speciation and the presence of $\mathrm{Ca}$ (Marschner, 2012). Thus, because Ca deficiency in grapevine occurs primarily on soils with a very low $\mathrm{pH}$ because the highly toxic $\mathrm{Al}$ becomes very soluble at $\mathrm{pH}<5.0$ and blocks Ca uptake, liming is an important practice to achieve profitable grape production in vineyards established on acid soils.

Liming is the most widely used long-term method of soil acidity amelioration. The addition of limestone materials to the soil increases the $\mathrm{pH}$ above 5.5, which promotes the precipitation of $\mathrm{Al}$ as $\mathrm{Al}(\mathrm{OH})_{3}$ and causes its elimination from the soil solution and the exchange complex. In addition to reducing the $\mathrm{Al}$ content of the soil, the application of adequate quantities of liming materials to acid soils encourages various beneficial chemical and biological changes in the soil: liming improves the structural conditions (aeration) and increases the bioavailability of phosphorus $(\mathrm{P}), \mathrm{Ca}$, magnesium $(\mathrm{Mg})$, and molybdenum (Mo) (Fageria \& Baligar, 2008).

Modern viticulture requires the implementation of efficient, sustainable and environmentally sound management practices. In this context, sugar foam is a relatively recently used organic liming material that has emerged because of the development of the beet sugar industry (García et al., 2009). Sugar foam is highly rich in active lime. In addition, 
it contains abundant organic matter, as well as other nutrient elements such as $\mathrm{P}$, iron $(\mathrm{Fe})$, copper $(\mathrm{Cu})$ and zinc $(\mathrm{Zn})$ (Vidal et al., 2006). In recent years, this residue obtained from the manufacturing of sugar has increasingly been recognized as a serious alternative as a liming material in Spain to improve the agro-soil-plant system in its chemical (García et al., 2009; Pérez de los Reyes et al., 2013a) and physical properties (Pérez de los Reyes et al., 2011).

The main objective of this study was to evaluate the effect of different doses of sugar foam amendment on the $\mathrm{pH}$ in water and the exchangeable cation contents, as well as on petiole $\mathrm{Ca}$ contents at véraison in an acid soil dedicated to Vitis vinifera L. cv. 'Mencía' cultivation over three years. In addition, a predictive model to explain the content of exchangeable $\mathrm{Ca}$ at véraison as a basis for developing liming recommendations and determining cane $\mathrm{Ca}$ contents at leaf fall was evaluated.

\section{MATERIALS AND METHODS \\ Study site}

A commercial vineyard, located $560 \mathrm{~m}$ above sea level in the municipality of Villafranca del Bierzo (León, Spain), with geographic coordinates of $42^{\circ} 35^{\prime} \mathrm{N}$ latitude and $6^{\circ} 46^{\prime} \mathrm{W}$ longitude, was selected as the study site. The mean annual reference evapotranspiration (FAO Penman-Monteith) is $922 \mathrm{~mm}$, while the mean annual rainfall is $616 \mathrm{~mm}$; the mean monthly temperature varies from $20.0^{\circ} \mathrm{C}$ (July) to $4.5^{\circ} \mathrm{C}$ (January) (estimations performed for the period 2000 to 2011) (SIAR, 2012). From a climatic point of view, the grape-growing region would be classified as Region I ( $\leq 1390$ Celsius degree-days) based on the system devised by Amerine and Winkler (Jackson, 2008). The soil under study corresponds to an Inceptisol, suborder Xerept, group Haploxerept according to the Soil Survey Staff (2010), and to Cambisol Dystric according to the FAO (2006).

The research was conducted on the Vitis vinifera L. cv. Mencía variety grafted onto a Richter 110 rootstock with an age of 75 years. Planting lines displayed an eastwest orientation. The conduction system involved head training, and there were four to five spurs per plant. Winter pruning left a thumb-sized arm with two buds. There was no summer pruning. The vineyard had no irrigation system support. No fertilisers or extra amendments other than that proposed in this research were implemented during the study period and during the years of monitoring, and the soil on which the vineyard grew did not undergo any type of tillage. A traditional vineyard soil management practice of local growers in vine rows (using herbicide in the spring before budburst) was implemented annually to alleviate weed competition.

\section{Sugar foam dose}

The liming doses used in the trial were chosen from those routinely employed by local winegrowers. Doses of 900, 1800 and $2700 \mathrm{~kg}$ calcium carbonate equivalent (CCE, defined as the acid-neutralising capacity of the material regarding pure $\mathrm{CaCO}_{3}$ ) per ha were tested, which corresponded to 1177,2354 and $3531 \mathrm{~kg}$ of sugar foam per ha. The sugar foam consisted of variable diameter aggregates, which were manually disaggregated before incorporation into the soil. In March 2006, after tillage to a depth of approximately $25 \mathrm{~cm}$, the amendment was manually applied and then incorporated into the soil using a second tillage pass. The sugar foam was provided by the La Bañeza (Leon, Spain) sugar factory, which is owned by British Sugar.

\section{Statistical design of the experiment}

The sugar foam was applied at three doses (900, 1800 and $2700 \mathrm{~kg} \mathrm{CaCO}_{3} /$ ha) with three repetitions per dose, providing nine subplots $(3 \times 3)$. In addition, three subplots were used as controls, yielding a total of 12 subplots. The treatments were distributed among the subplots in a completely randomised block design. Each subplot was approximately $24 \mathrm{~m}^{2}$ and consisted of eight vines planted in a line, although only the four middle plants in every subplot were sampled to avoid edge effects. For the same reason, the 12 subplots were distributed in three plant lines that were separated by three untreated buffer lines. The soil and plant data were tested for univariate normality (by the Shapiro-Wilk test), and then subjected to univariate analysis of variance using the general linear means procedure. The statistical analyses were performed using R 3.0.1. (R Core Team, 2013).

\section{Soil and plant analysis}

After the sugar foam was added, the effect of the liming on the following soil properties was monitored for three years (2006 to 2008): $\mathrm{pH}$ in water (pHw) and exchangeable $\mathrm{Ca}$, $\mathrm{Mg}, \mathrm{K}$ and $\mathrm{Al}$ saturation (CaECEC, MgECEC, KECEC and AlECEC, respectively). This monitoring was conducted by sampling soil a at depth of 0 to $30 \mathrm{~cm}$ at the véraison phenological stage. A total of three samplings (late August) were done over the study period. The air-dried soil samples were sieved to a diameter of $2 \mathrm{~mm} \varnothing$. Textural classes were determined by the Bouyoucos hydrometer method (1962). Official methods of analysis (MAPA, 1993) were used for the determination of (i) soil organic matter (SOM), (ii) $\mathrm{pHw}$ and electrical conductivity in a soil:water (1:2.5) suspension, and (iii) exchangeable bases, which were extracted with $1 \mathrm{M} \mathrm{NH}_{4} \mathrm{AcO}$ at $\mathrm{pH} 7$ and quantified by atomic absorption spectrometry ( $\mathrm{Ca}$ and $\mathrm{Mg}$ ) or flame emission spectrometry (K). The exchangeable Al was determined by inductively coupled plasma atomic emission spectroscopy (ICP-AES) using $1 \mathrm{~N} \mathrm{KCl}$ as the extraction agent (Little, 1964). The $\mathrm{P}$ levels were determined by visible molecular absorption spectroscopy after extraction with successive aliquots of sodium bicarbonate, following the method proposed by Olsen et al. (1954). The effective cation exchange capacity (ECEC) was obtained from the arithmetic sum of the concentrations of the exchangeable $\mathrm{Ca}^{2+}, \mathrm{Mg}^{2+}, \mathrm{K}^{+}$, and $\mathrm{Al}^{3+}$, whereas CaECEC, MgECEC, KECEC and AlECEC, were calculated from the relationship between the content of each of the exchangeable cations and the ECEC.

Calcium concentrations in petioles $\left(\mathrm{Ca}_{\mathrm{p}}\right)$ were evaluated through leaf sampling (30 petioles per subplot from basal leaves opposite bunches) at véraison (late August), whereas calcium concentrations in canes without bark $\left(\mathrm{Ca}_{\mathrm{C}}\right)$ were evaluated through cane sampling (15 canes per subplot) at leaf fall (early November). Both leaf and cane samples were analysed by inductively coupled plasma atomic emission spectroscopy (ICP-AES) after wet digestion. 


\section{RESULTS AND DISCUSSION}

Characterisation of the liming material and the soil before liming

Table 1 shows the mineral composition of the liming material used in this study (Villa, 2005). The Ca content of the sugar foam is due mainly to the presence of $\mathrm{Ca}$ in the form of slaked lime $\left[\mathrm{Ca}(\mathrm{OH})_{2}\right]$ and, to a lesser extent, as carbonate $\left(\mathrm{CaCO}_{3}\right)$ (Espejo, 2001).

Table 2 shows the baseline analytical data for the first $30 \mathrm{~cm}$ of the soil profile subsequently sampled in the study. The aluminium saturation $(\mathrm{Al} / \mathrm{ECEC})$ was very high at the start of the study $(76 \%)$ for the first $30 \mathrm{~cm}$ of the soil profile. In addition, low percentages of the exchangeable $\mathrm{Ca}$ and $\mathrm{Mg}$ saturation were evident.

\section{Soil exchange complex}

There was a highly significant effect of sugar foam dose on levels of $\mathrm{CaECEC}[\mathrm{F}(3,32)=12.2, \mathrm{P}<0.001]$ and AlECEC $[F(3,32)=6.6, P<0.01] . F$-ratios were large enough to be statistically significant in these soil properties, so post hoc tests (Tukey's honestly significant difference test) were done to know where the differences lay between groups. Sugar foam dose had no significant effect on $\mathrm{pHw}[\mathrm{F}(3,32)=2.1$, $\mathrm{P}=0.12], \operatorname{MgECEC}[\mathrm{F}(3,32)=2.6, \mathrm{P}=0.07]$ and $\mathrm{KECEC}$ $[\mathrm{F}(3,32)=1.8, \mathrm{P}=0.17]$.

Table 3 shows the post hoc tests between the soil property means. At a depth of 0 to $30 \mathrm{~cm}, \mathrm{CaECEC}$ tended to decrease significantly in the sequence $2700 / 1800>900 /$ control, whereas AlECEC tended to increase significantly in the sequences $2700<900 /$ control and $1800<$ control. The sugar foam doses had no significant effects on pHw, MgECEC and KECEC at the depth (0 to $30 \mathrm{~cm}$ ) studied. The overall effects of the higher doses of sugar foam (2 700 and $1800 \mathrm{~kg} \mathrm{CaCO}_{3} / \mathrm{ha}$ ) on the exchange complex are consistent with those found by Illera et al. (2004) and Vidal et al. (2006). Although the pHw does not change significantly, we can conclude that these agro-industrial products have a positive final effect on the quality of the acidic soil and can be considered as effective alternatives for traditional liming materials. In addition, although vine root depth was not measured, it could conceivably be hypothesised that an increase of CaECEC at the studied depth (and probably in the subsoil by leaching of $\mathrm{Ca}$ ) would be able to promote the penetration of vine roots into subsoil layers. The latter is in accordance with the fact that the uptake of $\mathrm{Ca}$ required for root growth is particularly problematic in acidic soils because of (i) poor physiological status of roots due to $\mathrm{Al}$ toxicity and (ii) relatively low $\mathrm{Ca}$ concentration in the soil solution (Marschner, 2012).

The potential impact of the toxic trace elements accumulated in the so-called sugar foam in soils used for grape production is undoubtedly of interest. It is important to bear in mind that high levels of trace elements in viticultural soils, such as cadmium $(\mathrm{Cd})$, chromium $(\mathrm{Cr})$, nickel $(\mathrm{Ni})$ or lead $(\mathrm{Pb})$, among others, can reduce vine growth or establish a serious risk for contamination of the food chain through bioaccumulation in the grapes (Naidu et al., 2004). Although it was not possible to investigate if the addition of sugar foam caused an increase in the content of soil trace elements, previous research by Pérez de los Reyes et al. (2013) with

TABLE 1

Chemical composition of the sugar foam expressed as dry matter.

\begin{tabular}{cccccccc}
\hline Treatment & $\mathbf{C a O}$ & $\mathbf{M g O}$ & $\begin{array}{c}\mathbf{N a}_{2} \mathbf{O} \\
(\mathrm{g} / \mathrm{kg})\end{array}$ & $\begin{array}{c}\mathbf{K}_{2} \mathbf{O} \\
(\mathrm{g} / \mathrm{kg})\end{array}$ & $\begin{array}{c}\mathbf{A l} \\
(\mathrm{g} / \mathrm{kg})\end{array}$ & $\begin{array}{c}\mathbf{O M} \\
(\mathrm{g} / \mathrm{kg})\end{array}$ & $\begin{array}{c}\mathbf{C C E} \\
(\mathrm{g} / \mathrm{kg})\end{array}$ \\
\hline Sugar foam & 403.8 & 14.5 & 0.4 & 0.9 & 2469 & 79.0 & 757 \\
\hline
\end{tabular}

OM: Organic matter; CCE: Calcium carbonate equivalent.

TABLE 2

Baseline soil characteristics of soil surface $(0$ to $30 \mathrm{~cm})$ before liming.

\begin{tabular}{lccccccc}
\hline Depth & Sand $(\%)$ & Silt $(\%)$ & Clay $(\%)$ & Textural class (USDA) & SOM $(\%)$ \\
\hline $0-30 \mathrm{~cm}$ & 52.6 & 26.0 & 21.3 & Sandy clay loam & 0.77 \\
\hline \multirow{2}{*}{$0-30 \mathrm{~cm}$} & $\mathbf{p H} \mathrm{w}_{\mathrm{w}}$ & $\mathbf{E C}(\mathrm{dS} / \mathrm{m})$ & CaECEC $(\%)$ & MgECEC $(\%)$ & KECEC $(\%)$ & AlECEC $(\%)$ & ECEC $(\mathrm{cmol}(+) / \mathrm{kg})$ \\
& & 0.04 & 10.70 & 6.40 & 7.60 & 75.30 & 2.49 \\
\hline
\end{tabular}

TABLE 3

Effect of the sugar foam dose (in $\mathrm{kg} \mathrm{CaCO}_{3}$ per ha) on pHw and exchangeable complex, 2006 to 2008.

\begin{tabular}{lccccc}
\hline Dose & pHw & CaECEC $(\%)$ & MgECEC $(\%)$ & KECEC $(\%)$ & AlECEC $(\%)$ \\
\hline Control & $4.56 \pm 0.05 \mathrm{a}$ & $14.6 \pm 2.1 \mathrm{~b}$ & $6.2 \pm 1.2 \mathrm{a}$ & $8.0 \pm 1.7 \mathrm{a}$ & $71.2 \pm 3.9 \mathrm{a}$ \\
900 & $4.73 \pm 0.08 \mathrm{a}$ & $20.0 \pm 4.2 \mathrm{~b}$ & $8.6 \pm 1.9 \mathrm{a}$ & $6.3 \pm 0.8 \mathrm{a}$ & $65.2 \pm 6.3 \mathrm{ab}$ \\
1800 & $4.74 \pm 0.07 \mathrm{a}$ & $32.4 \pm 3.3 \mathrm{a}$ & $9.2 \pm 1.0 \mathrm{a}$ & $5.4 \pm 0.6 \mathrm{a}$ & $53.0 \pm 3.8 \mathrm{bc}$ \\
2700 & $4.77 \pm 0.06 \mathrm{a}$ & $36.4 \pm 1.3 \mathrm{a}$ & $11.1 \pm 0.3 \mathrm{a}$ & $4.9 \pm 0.5 \mathrm{a}$ & $47.6 \pm 1.6 \mathrm{c}$ \\
\hline
\end{tabular}

Means ( \pm standard error) in the same column that are followed by the same letter do not differ at $\mathrm{P}=0.05$. 
sugar foam showed that, after an amendment of an acidic vineyard soil (Tipic Palexerult according to Soil Survey Staff, 2010), levels of barium (Ba), rubidium ( $\mathrm{Rb}$ ) and strontium (Sr) were increased in the amended soil in comparison to the original soil. In accordance with viticultural concepts of vineyard soil quality and sustainability, future studies on the current topic therefore are recommended.

\section{Development of the CaECEC predictive model}

A predictive model to explain the content of calcium in the exchange complex at véraison as a basis for developing a liming recommendation system was developed. We proceeded to model the CaECEC as a function of the sugar foam dose in $\mathrm{kg} \mathrm{CaCO}_{3} /$ ha. The sum of squares was decomposed into a linear, quadratic and cubic term. Powers of dose beyond a one-order polynomial did not make significant contributions to explaining the variation in $\mathrm{Ca}$ in the exchange complex at véraison. Only linear terms produced a significant F-statistic $(\mathrm{P}<0.001)$ (Table 4).

The Akaike Information Criteria (AIC) provides another method for comparing models. Models with AIC not differing by 2 should be treated as equally adequate, but the one with the lower AIC should be adopted (Chatterjee \& Hadi, 2006). In addition, the selection of a final regression model involves a compromise between predictive accuracy and parsimony. Thus, a linear model (AIC $=262.2)$ was selected as being more adequate than a quadratic model $(\mathrm{AIC}=264.1)$ and a cubic model $(\mathrm{AIC}=264.6)$.

In the proposed model, the coefficient of determination, $\mathrm{R}^{2}$, represents the variance in the CaECEC that was explained by the predictive model. Thus, in the linear model proposed, the sugar foam dose could explain $51 \%$ of the variance in the CaECEC values. Fig. 1 shows a plot of the fitted linear model with prediction (inner) and confidence (outer) bands. The equation for the linear model including the sugar foam doses (D, in $\mathrm{kg} \mathrm{CaCO}_{3} / \mathrm{ha}$ ) is:

$$
\operatorname{CaECEC~}(\%)=14.1+0.016 \mathrm{D}
$$

When prediction is the primary goal in a regression equation, the selection and interpretation of the regression model does not signal the end of the labour. Instead, methods for assessing model generalisability should be considered. Thus, to assess the generalisability of the linear model proposed in this work, a cross-validation method was developed. In k-fold cross-validation, the initial data are randomly partitioned into $\mathrm{k}$ mutually exclusive subsets or folds, each of approximately equal size. Training and testing are performed $\mathrm{k}$ times. We used the commonly accepted 10-fold application (Harrell, 1998), so, in this situation, the model was trained using nine of the tenths and prediction error was computed on the remaining one tenth. The root of the cross-validation residual sums of squares, which is a corrected measure of prediction error averaged across all folds, from the CaECEC levels obtained from the proposed model was $8.9 \%$.

If achieving a percentage of CaECEC in ECEC of $70 \%$ is fixed as a desirable level for grapevine performance (Abbott, cited by Hazelton \& Murphy, 2007), our model predicts that the dose of sugar foam required would be $3494 \mathrm{~kg}$ $\mathrm{CaCO}_{3} / \mathrm{ha}$, that is far from the higher liming doses tested in the trial.

However, because soils are extremely diverse and their characteristics have large time and spatial variability, it would be necessary to verify all the results obtained in this work for their suitability for practical application through long-term field experiments. In addition, soil processes are strongly dependent on weather conditions in a given year (Körschens, 2006). Thus, although the findings of this work may help us to understand the practice of liming with sugar foam in terms of making decisions about the need for lime, more research on this topic therefore is recommended to understand how environmental changes or soil variability may influence the results.

\section{Petiole and cane Ca concentrations}

Table 5 shows the mean values for $\mathrm{Ca}_{\mathrm{P}}$ and $\mathrm{Ca}_{\mathrm{C}}$ monitored in the test plots during the three years of the trial. Sugar foam dose had no significant effect on $\mathrm{Ca}_{\mathrm{P}}[\mathrm{F}(3,32)=2.2$, $\mathrm{P}=0.11]$ and $\mathrm{Ca}_{\mathrm{C}}[\mathrm{F}(3,32)=0.5, \mathrm{P}=0.72]$. However, $\mathrm{Ca}_{\mathrm{P}}$ increased with increasing sugar foam application rate in the sequence Control $<500<1000<1500$, whereas $\mathrm{Ca}_{\mathrm{C}}$ decreased with increasing sugar foam application rate in the sequence Control $>900>1800 / 2700$.

In the same way as in this research, Wooldridge et al. (2010) previously reported an increase in the calcium petiole concentration by the application of liming materials in field tests. However, the trial of these researchers was conducted at fruit-set. If achieving a concentration of calcium in the petiole of $1.5 \%$ is fixed as an adequate level at véraison to

TABLE 4

Analysis of variance for the CaECEC response to four levels of sugar foam over three years, 2006 to 2008.

\begin{tabular}{llllll}
\hline Source & Degrees of freedom & Sum of squares & Mean square & F & Significance \\
\hline Sugar foam dose & 3 & 2852 & 951 & 12.2 & $* * *$ \\
Linear regression & 1 & 2740 & 2740 & 35.3 & $* * *$ \\
Quadratic regression & 1 & 3.99 & 3.99 & 0.05 & 0.82 \\
Cubic regression & 1 & 108 & 108 & 1.38 & 0.25 \\
Residual & 32 & 2485 & 77.7 & & \\
Total & 35 & 5337 & & & \\
\hline
\end{tabular}

* significant at the 0.05 probability level $(\mathrm{P}<0.05)$; ** significant at the 0.01 probability level $(\mathrm{P}<0.01)$; *** significant at the 0.001 probability level $(\mathrm{P}<0.001)$. 
avoid nutritional deficiencies (Fregoni, cited by Bavaresco et al., 2010), none of the petiole Ca concentrations in the test plots were in adequate nutritional ranges. This is consistent with the suboptimal percentages of exchangeable calcium (CaECEC) in all the sugar foam doses tested.

Figure 2 shows the relationship between $\mathrm{Ca}_{\mathrm{p}}$ concentration and $\mathrm{CaECEC}$ at véraison with dose of sugar foam (in $\mathrm{kg} \mathrm{CaCO}_{3} / \mathrm{ha}$ ) as a conditioning variable. As can be seen, $\mathrm{Ca}_{\mathrm{p}}$ increases as $\mathrm{CaECEC}$ increases. Consequently, the largest concentrations of $\mathrm{Ca}_{\mathrm{p}}$ were obtained with sugar foam doses that were more effective in increasing $\mathrm{Ca}$ saturation in the soil exchange complex, concomitant in the subplots with a major decrease of $\mathrm{Al}$ saturation in the soil exchange complex.

Figure 3 shows the average total $\mathrm{Ca}_{\mathrm{C}}$ concentration for each sugar foam dose obtained in the three cropping years

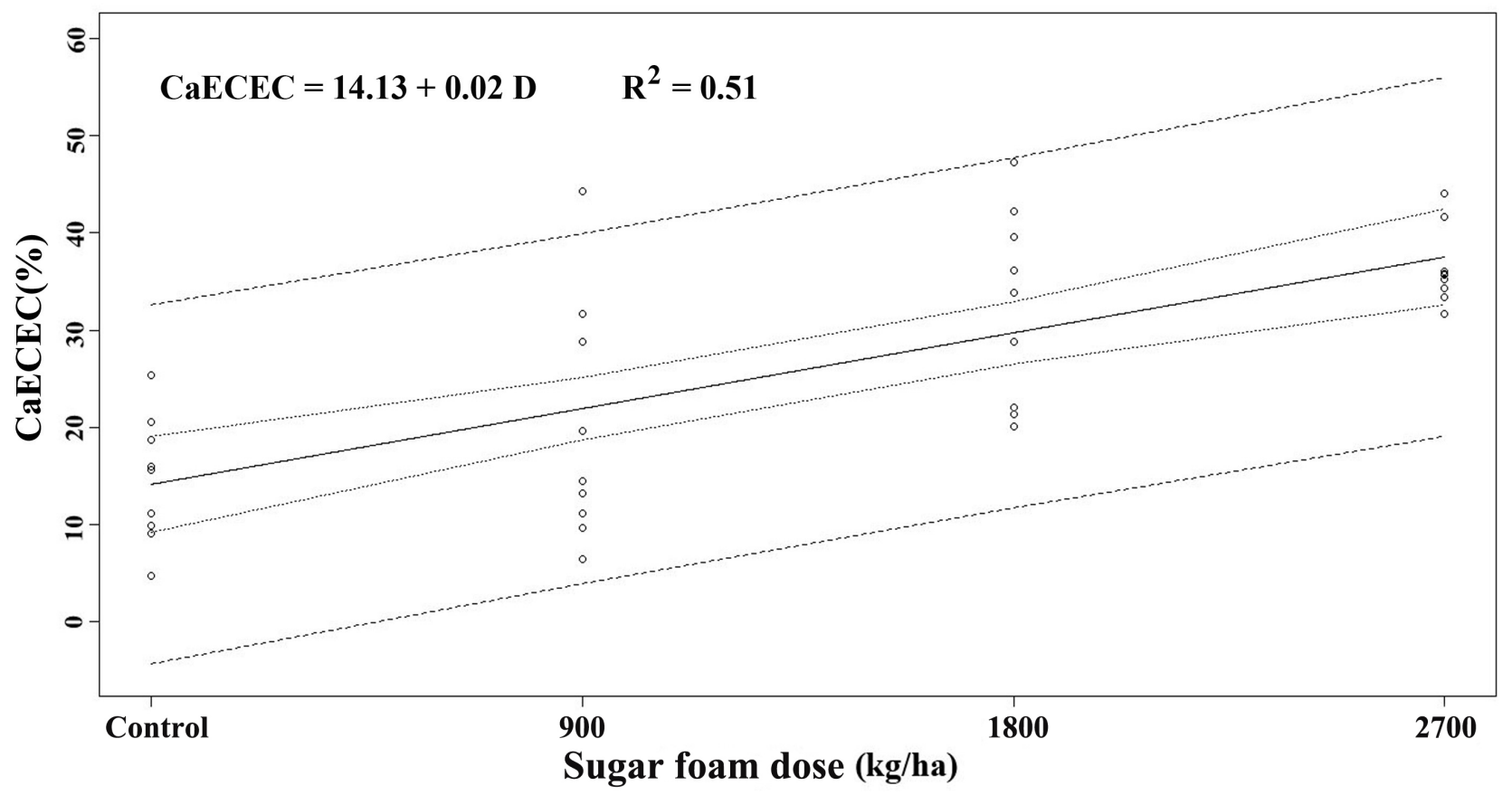

FIGURE 1

Linear model of exchangeable $\mathrm{Ca}$ (CaECEC) prediction with confidence and prediction limits (2006 to 2008). Sugar foam dose (D) in $\mathrm{kg} \mathrm{CaCO}_{3} / \mathrm{ha}$.

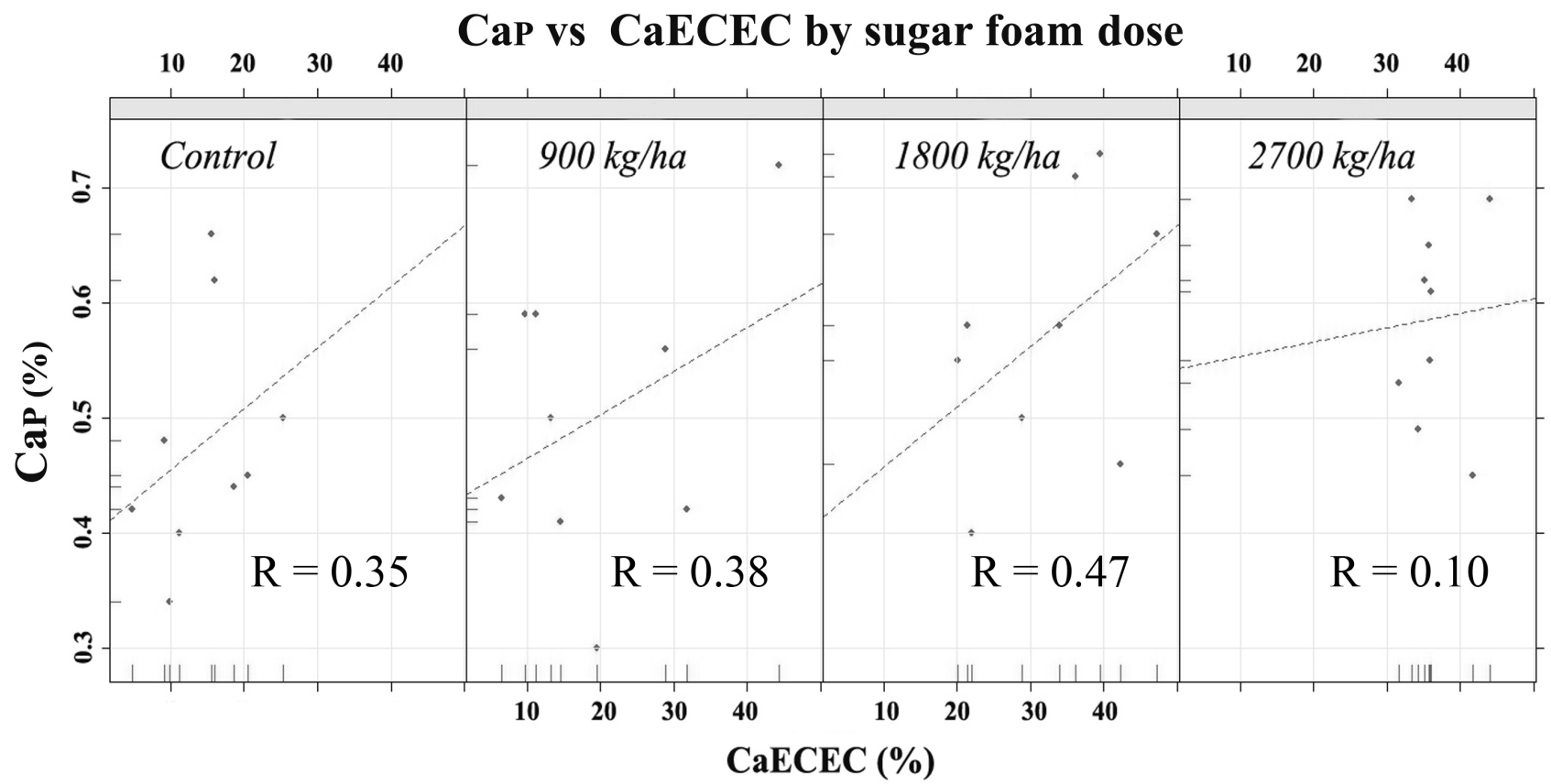

FIGURE 2

Relationship between calcium concentration in petioles $\left(\mathrm{Ca}_{\mathrm{p}}\right)$ and exchangeable calcium $(\mathrm{CaECEC})$ at véraison by sugar foam dose ( $\mathrm{kg} \mathrm{CaCO}_{3} / \mathrm{ha}$ ), 2006 to 2008. $\mathrm{R}$ is the bivariate correlation coefficient. 


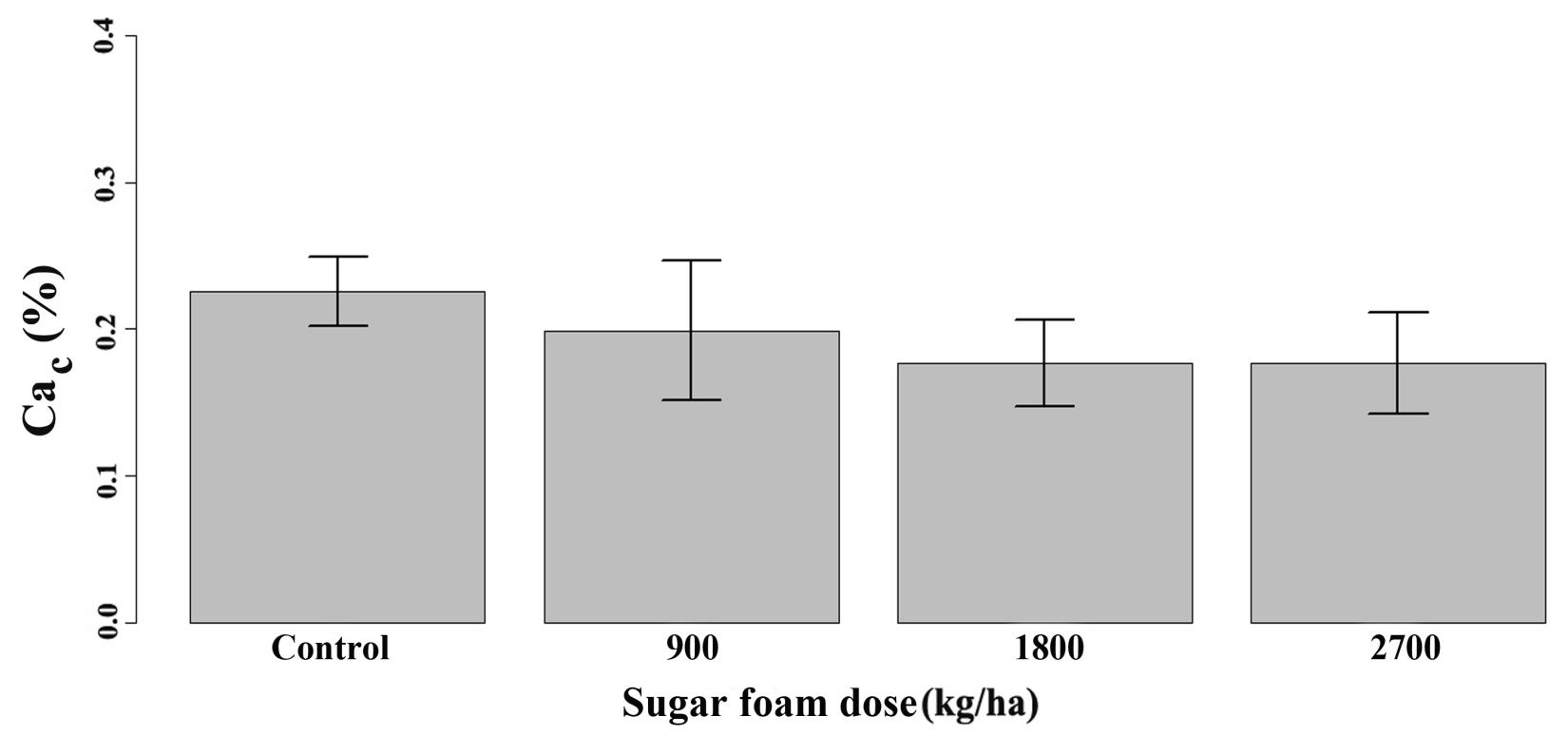

FIGURE 3

Average values of calcium concentrations in canes $\left(\mathrm{Ca}_{\mathrm{C}}\right.$, as dry matter percentage) during the three cropping years (2006 to 2008) by sugar foam dose $\left(\mathrm{kg} \mathrm{CaCO}_{3} / \mathrm{ha}\right)$. Standard errors ( $\mathrm{SE}$ mean) are shown as bars $( \pm 1 \times \mathrm{SE}$ mean).

TABLE 5

Effect of the sugar foam dose (in $\mathrm{kg} \mathrm{CaCO}_{3}$ per ha) on $\mathrm{Ca}_{\mathrm{p}}$ and $\mathrm{Ca}_{\mathrm{C}}, 2006$ to 2008.

\begin{tabular}{lcc}
\hline Dose & $\mathbf{C a}_{\mathbf{P}} \mathbf{( \% )}$ & $\mathbf{C} \mathbf{a}_{\mathbf{C}} \mathbf{( \% )}$ \\
\hline Control & $0.48 \pm 0.03 \mathrm{a}$ & $0.23 \pm 0.02 \mathrm{a}$ \\
900 & $0.50 \pm 0.04 \mathrm{a}$ & $0.20 \pm 0.05 \mathrm{a}$ \\
1800 & $0.57 \pm 0.04 \mathrm{a}$ & $0.18 \pm 0.03 \mathrm{a}$ \\
2700 & $0.59 \pm 0.03 \mathrm{a}$ & $0.18 \pm 0.03 \mathrm{a}$ \\
\hline
\end{tabular}

Means ( \pm standard error) in the same column that are followed by the same letter do not differ at $\mathrm{P}=0.05$.

(2006 to 2008). In contrast to the effect that normally would be expected after liming, $\mathrm{Ca}_{\mathrm{C}}$ decreased with increasing sugar foam dose. However, the effects of liming on the calcium levels of canes have not been studied to date. Notwithstanding the foregoing, these data must be interpreted with caution because it is important to bear in mind the chemical digestion carried out in this investigation (an acid mixture of perchloric, sulphuric and nitric acid). It therefore may be the case that another procedure of cane digestion (pressure digestion or microwave digestion) will show different results on $\mathrm{Ca}_{\mathrm{C}}$ than those obtained in this work. Thus, future research should be concentrated in this area.

\section{CONCLUSIONS}

The field application of sugar foam increased the amount of $\mathrm{Ca}$ and decreased that of $\mathrm{Al}$ in the exchange complex of the surface horizon in an acid soil dedicated to grapevine cultivation. A linear model is proposed to represent the variance in the CaECEC at veraison. The coefficient of determination obtained was moderate. A more accurate model, in terms of variance explained, would require testing higher sugar foam doses. Based on the results of the threeyear experiment, liming with sugar foam did not significantly affect $\mathrm{Ca}$ contents in petioles and canes. However, the calcium content in the petioles was higher in soils treated with sugar foam. In this way, the use of sugar foam is an interesting industrial by-product alternative to other liming materials. The results of the $\mathrm{Ca}$ content in canes were controversial. Future research therefore should concentrate on the investigation of this area.

\section{LITERATURE CITED}

Bouyoucos, G., 1962. Hydrometer method improved for making particle size analyses of soils. Agron. J. 54, 464-465.

Bavaresco, L., Gatti, M. \& Fregoni, M., 2010. Nutritional deficiencies. In: Delrot, S., Medrano, H., Or, E., Bavaresco, L. \& Grando, S. (eds). Methodologies and results in grapevine research. Springer, Dordrecht. pp $165-191$.

Chatterjee, S. \& Hadi, A.S., 2006 ( $4^{\text {th }}$ ed). Regression analysis by example. John Wiley \& Sons, Inc., Hoboken.

Espejo, R., 2001. El uso de la espuma de azucarería, fosfoyeso y residuos dolomíticos de convertidor como enmendantes de suelos ácidos. In: Proc. 1st Int. Congr. Manage. Org. Waste Rural Land Grange Areas, Pamplona, Spain. pp $377-386$.

Fageria, N.K. \& Baligar, V.C., 2008. Ameliorating soil acidity of tropical Oxisols by liming for sustainable crop production. Adv. Agron. 99, 345-399.

FAO (Food and Agriculture Organization of the United Nations), 2006. World reference base for soil resources. World soil resources reports No. 103. FAO, Rome.

García, F.J., Amorós, J.A., Sánchez, C.J., Bravo, S., Márquez, E. \& Jiménez, R., 2009. Application of sugar foam to red soils in a semiarid Mediterranean environment. Environ. Earth Sci. 59(3), 603-611.

Harrell, F., 1998. Comparisons of strategies for validating binary logistic regression models. URL: http://biostat.mc.vanderbilt.edu/twiki/pub/Main/ RmS/logistic.val.pdf [Accessed July, 2013]. 
Hazelton, P. \& Murphy, B., 2007. Interpreting soil test results. CSIRO Publishing, Collingwood.

Illera, V., Garrido, F., Vizcayno, C. \& García-González, M.T., 2004. Field applications of industrial by-products as Al toxicity amendments: chemical and mineralogical implications. Eur. J. Soil Sci. 55, 681-692.

Jackson, R.S., 2008 ( $3^{\text {rd }}$ ed). Wine science. Principles and applications. Academic Press, Elsevier Inc., Burlington.

Kochian, L.V., Piñeros, M.A. \& Hoekenga, O.A., 2005. The physiology, genetics and molecular biology of plant aluminum resistance and toxicity. Plant Soil 274, 175-195.

Körschens, M., 2006. The importance of long-term field experiments for soil science and environmental research-a review. Plant Soil Environ. 52, $1-6$.

Little, I., 1964. The determination of exchangeable aluminium in soils. Aus. J. Soil Res. 2, 76-82.

Marschner, P., 2012 (3rd ed). Marschner's mineral nutrition of higher plants. Academic Press, Elsevier Inc., London.

MAPA, 1993. Métodos oficiales de análisis, vol. III. Ministerio de Agricultura, Pesca y Alimentación, Secretaría General Técnica, Madrid.

Menzies, N.W., 2003. Toxic elements in acid soils: Chemistry and measurement. In: Rengel, Z. (ed.). Handbook of soil acidity. Marcel Dekker, Inc., New York. pp. $267-296$.

Naidu, R., Megharaj, M. \& Owens, G., 2004. Recyclable urban and industrial waste. Benefits and problems in agricultural use. In: Schjønning, P., Elmholt, S.. \& Christensen, B.T. (eds). Managing soil quality. Challenges in modern agriculture. CABI Publishing, Wallingford. pp $219-237$.

Olsen, S.R., Cole, C.V., Watanabe, F.S. \& Dean, L.A., 1954. Estimation of available phosphorus in soils by extraction with sodium bicarbonate, USDA, circular 939. United States Government Printing Office, Washington, DC.
Pérez de los Reyes, C., Amorós, J.A., García, F.J., Bravo, S. \& Jiménez, R., 2013a. Grapevine leaf uptake of mineral elements influenced by sugar foam amendment of an acidic soil. Vitis 52(4), 157-164

Pérez de los Reyes, C., Amorós, J.A., García, F.J., Bravo, S., Sánchez C, Chocano, D. \& Jiménez, R., 2011. Changes in water retention properties due to the application of sugar foam in red soils. Agr. Water Manage. 98(4), 1834-1839.

R Core Team, 2013. R: A language and environment for statistical computing. R Foundation for Statistical Computing, Vienna. URL: http:/ www.R-project.org/ [Accessed May, 2013].

SIAR, 2012. Sistema de Información Agroclimática para el Regadío. Ministerio de Agricultura, Pesca y Alimentación, Madrid. URL: http:// www.magrama.gob.es/siar/ [Accessed July, 2012]

Soil Survey Staff, 2010 (11 ${ }^{\text {th }}$ ed). Keys to soil taxonomy. USDA. Natural Resources Conservation Service, Washington, DC.

Sumner, M.E. \& Noble, A.D., 2003. Soil acidification: The world story. In Rengel, Z. (ed.). Handbook of soil acidity. Marcel Dekker, Inc., New York. pp $1-28$.

Vidal, M., Garzón, E., García, V. \& Villa, E., 2006. Differentiating the amending effects of calcareous materials applied to acid soils by use of optimal scaling procedures. Agrochimica 50(3-4), 132-147.

Villa, E., 2005. Incidencia de la aplicación de espumas de azucarería y otras enmiendas calizas sobre la producción de biomasa. Mejora a corto plazo de los condicionantes agronómicos de los suelos ácidos de raña del norte de León. Thesis, Universidad de León, Avenida Facultad de Veterinaria 25, 24004, León, Spain.

Wooldridge, J., Louw, P.J.E. \& Conradie, W.J., 2010. Effects of liming to near-neutral pH on Vitis vinifera L. S. Afr. J. Enol. Vitic. 31(1), 45-48. 